\section{Activities of the Foundation}

To turn the above vision into action: first, the Foundation is setting up a Centre for Research on Sustainable Agricultural and Rural Development - at the Institutional Complex, Taramani, Madras, on land kindly made available by the Government of Tamil Nadu. This Centre will focus attention on:

1. Programmes for conservation, evaluation, and utilization, of India's biological wealth, with an initial emphasis on coastal ecosystems;

2. Development of methodology to measure and monitor sustainability in the improvement of biological productivity;

3. Technology development and information dissemination to enhance opportunities for skilled employment; and

4. Anticipatory research on problems relating to changes in sea-levels, precipitation, and temperature.

Second, the Foundation will organize workshops on issues relating to science and society, involving both social scientists and those engaged in the leading edge of technology development and dissemination, instructional programmes for trainers, and demonstrations and operational research involving local communities of farmers and fishermen.

Third, the Foundation will set up an Information and Communications Centre for developing data bases, computer-simulation models, and computer-aided instructional and extension techniques.

\section{The Centre for Research on Sustainable Agricultural and Rural Development}

Of this the main objectives are:

(a) to integrate equity and sustainability in technology development and dissemination;

(b) to harmonize the demands of intra-generational and inter-generational equity, or equity of present and future; and

(c) to promote pro-active research and action in relation to equity and sustainability.

The Centre will take up the following four research projects during 1989-94:

Project I - Designing and Implementing a Coastal Systems Research (CSR) programme for promoting the Sustainable Management of Coastal Ecosystems.

Project II - Increasing Opportunities for Skilled Employment in Rice-farming Areas.

Project III - Organization of a Genetic Resources Centre for Adaptation to Climatic Changes.

Project IV - Research on Organizational and Delivery Systems for Enhancing the Efficiency of Smallfarm Management.

\section{Tasks Ahead}

The Research Foundation and its associated Centre for Research on Sustainable Agricultural and Rural Development will establish the minimum essential laboratory and computational facilities at Madras. The Genetic Resources Centre will be established with the help of the Forest Department of the Government of Tamil Nadu, and the Research Foundation will work in close collaboration with other existing institutions and universities that are interested in similar areas of research, training, and demonstration.

For further information about this Research Foundation and its objectives, please contact the undersigned:

\section{Monkombu S. SWAminathan, FNA, FRS, Director M.S. Swaminathan Research Foundation \\ Il Rathna Nagar, Teynampet \\ Madras 600018, India.}

Tel. (044) 455339

Fax. 9144478148

\title{
Council of Europe Campaign to Protect Freshwater Fish and Their Biotopes*
}

The Centre Naturopa of the Council of Europe has just officially launched the International Campaign for the Conservation of Freshwater Fish. The Campaign will appeal for better knowledge of this marvellous natural heritage, emphasize the diversity of species, and warn against the growing danger which threatens them and alters their biotopes. In fact, fish are valuable bio-indicators of the quality of water-a vital 'element' for fishes but also for Mankind.

The Campaign has already got off to a good start in a number of European countries. Others will follow, and Naturopa Newsletters will report on activities 'round and about'. Initially, Naturopa Newsletter No 90, of June

\footnotetext{
* A biotope is the smallest subdivision of a habitat which is characterized by a high degree of uniformity as regards both environmental conditions and biotic inhabitants. The biotope is not to be confused with the niche which, following $C$. S. Elton as regards animals, we define in terms of the place of a plant or animal in its biotic environment and what it is doing there. Such features as the mobility of most taxa of fishes, involving usually several biotopes, commonly different ecosystems, and sometimes a multiplicity even of ecobiomes, makes us wonder whether some other term is not needed to describe their positional ecological status. - Ed.
}

1990 , has a leading article by the undersigned, Chairman of the Steering Committee for the Conservation and Management of the Environment and Natural Habitats (CDPE), on the place of the Campaign in the Nature and environmental conservation activities of the Council of Europe. Following this, an ichthyologist analyses the scientific reasons for choosing this Campaign. Thereafter are considered the various events already planned in connection with the Campaign in Austria, France, Liechtenstein, Luxembourg, and Switzerland, as well as the contact addresses in these countries as follows:

Austria: Dr Durolf Hofer, Institute of Zoology, University of Innsbruck, Technikerstrasse 25, A 6020 Innsbruck, Austria.

France: Mr Hervé Lethier, Mrs M. F. Bossenie, Service Pêche et Hydrobiologie, Direction de la Protection de la Nature, 14 Boulevard du Général Leclerc, F 92524 Neuilly-sur-Seine, Cedex, France.

Liechtenstein: $\mathrm{Mr}$ Wilfried Marxer-Schädler, Liechtensteinische Gesellschaft für Umweltschutz, Heiligkreuz 52, FL 9490 Vaduz, Liechtenstein.

Luxembourg: Direction des Eaux et Forêts, Service de la Chasse et de la Pêche, BP 411, L 2014 Luxembourg. 
Switzerland: Dr Ulrich Halder, LSPN, Postfach, CH. 4020 Basel, Switzerland.f

The conservation of Nature and natural resources has a prime place in the work of the Council of Europe, where it has already a long tradition of well-deserved successes. Since 1962 there has been a European Committee to provide the essential coordination to tackle, in the framework of a European 'strategy', the Nature conservation problems which have become increasingly numerous and acute. The result of these efforts is marked, inter alia, by the many resolutions and recommendations adopted by the Committee of Ministers, the European information campaigns for the general public, and the high-quality scientific publications in the "Nature and Environment' series. Even in this brief overview it is impossible to forget the Committee's major achievement: the preparation of the Convention on the Conservation of European Wildlife and Natural Habitats (widely known as the Bern Convention), which has been in force since 1982.

The problems of protecting freshwater bodies and freshwater fishes could not be ignored by the European Committee, which is seeking to protect Nature from overwhelming economic development. So in 1968 there appeared the Water Charter and a brochure on fresh

$\dagger$ In addition we can now cite Portugal: Mr Luis Miguel Vieira, Vice-President, Liga Para a Proteccao da Natureza, Estrada do Calhariz de Benfica No. 187, P-1500 Lisbon, Portugal. - Ed. water, followed in 1980 by a publication specifically on endangered freshwater fishes in Europe and, in 1981, the Committee of Ministers' recommendations on freshwater fishes. These activities were a prelude to including endangered species in the annexes of the Bern Convention.

The Campaign which the Council of Europe is launching in 1990, with issue No 90 of Naturopa Newsletter, is an ideal follow-up to the activities mentioned above and also one response to the increasingly serious threats affecting the biotopes of fish species throughout Europe and also jeopardizing conservation of their biological diversity. Deplorably, the very nature of freshwater lakes and watercourses is being distorted by the building of hard embankments and the use of hydraulic force, by the pressure of tourism and leisure activities, and by the addition of chemical products from agriculture or rainfall and/or dust. Energetic countermeasures are needed urgently, and for that public opinion must be aroused and won over to the 'freshwater fishes cause'.

The European Committee thanks the Centre Naturopa and all the National Agencies attached to it for their welcome initiative, and wishes the Campaign the entire success that it truly needs.

\section{Aldo ANTONIETTI, CDPE Chairman clo Centre Naturopa Boîte postale 431 R6 F-67006 Strasbourg Cedex France.}

\section{The European Environmental Campus Scheme}

This initiative has been set up to run for the first time this year, with funding from the European Commission's Directorate General for the Environment. The aim of the European Environmental Campus scheme is to foster cooperation throughout Europe, amongst academics, students, and practitioners, who have a common concern for the environment.

In the short term this cooperation takes the form of concurrent research projects which are run by each of the nine 'Campuses' that are participating in the scheme this summer. These projects are to be conducted by teams of between 10 and 15 students each, with different academic backgrounds and cultural values, drawn from all over Europe. There will thus be a unique opportunity for students to compare the undergraduate curricula of a number of subjects in a number of different countries.

The projects have been devised, and are to be run, by professional staff from the universities and colleges involved. For example in Portugal, students are to participate in a large ethnographic and environmental study of the High Algarve that is being conducted by Faro Polytechnic, by developing an inventory of environmental resources in the region.

At Roskilde University in Denmark there is a project to investigate the environmental impacts of intensive agriculture, whilst at Nantes University, in France, the environmental protection of large river estuaries is the principal concern. In Italy, at Florence University, and in Greece and Great Britain, the projects all focus on the interface between tourism and the environment. They are concerned to develop strategies for tourism that are environmentally sustainable. In Belgium and Spain the central interest lies in the development of rural communities in an environmentally sensitive way.

When this year's programmes have been evaluated, it is the intention of the Campuses in the medium-term that individual research projects, such as the ones that are being run this year, can be formalized into free-standing modules that will fit into the undergraduate environmental degree programmes of each of the Campuses. In this way, students will be able to pursue degrees in their own countries but with specific modules on these programmes available in other parts of Europe.

In the longer-term there is the aspiration of a panEuropean degree in Environmental Sciences. This would be made up largely of modules offered by the Campuses, and would belong to them all collectively. It would be a degree that should be validated in all European countries and would have a uniquely European perspective on environmental problems while involving a multinational community of students.

NIGEL R. CURRY, Director of Research
Faculty of Environment and Leisure
Cheltenham and Gloucester College
of Higher Education
The Park
Cheltenham
Gloucestershire GL5O 2RH
England, UK.

